\title{
Spine Cancer pT4b TNM Finding v8
}

National Cancer Institute

\section{Source}

National Cancer Institute. Spine Cancer pT 4b TNM Finding v8. NCI Thesaurus. Code C136590.

Spine cancer with evidence of gross vascular invasion or tumor thrombus in the great vessels. (from AJCC 8th Ed.) 